\title{
Nucleolar organiser regions in kidney tumours and xanthogranulomatous pyelonephritis
}

\author{
R L Bryan, J Crocker, A Farr
}

\begin{abstract}
The AgNOR argyrophil technique was applied to clear cut examples of renal adenoma $(\mathbf{n}=7)$, clear cell carcinoma $(\mathbf{n}=9)$, and xanthogranulomatous pyelonephritis $(n=5)$. There was no significant difference between mean AgNOR counts per cell in adenomas and carcinomas, supporting the idea that there is a continuous spectrum of kidney tumours. Xanthogranulomatous pyelonephritis and clear cell carcinoma showed significant differences in mean AgNOR counts per cell, suggesting that the technique may be of use in distinguishing between these conditions, although further cases may need to be examined to confirm this.
\end{abstract}

Renal adenoma and carcinoma are derived from proximal or distal tubular epithelial cells of the kidney. ${ }^{1-3} \mathrm{~A}$ diameter of $3 \mathrm{~cm}$ has been taken as the dividing line between these two types of tumour, although tumours larger than this are found without metastases and smaller tumours may be seen with metastases. Some authors do not recognise renal adenoma as an entity and regard tumours of less than $3 \mathrm{~cm}$ in diameter as early carcinomas. The histological appearances of renal adenoma and carcinoma are often identical. ${ }^{4}$

Xanthogranulomatous pyelonephritis is an inflammatory condition usually spreading from the calyceal areas of the kidney and is associated with urinary obstruction and infection. The condition may produce a tumour-like mass in the kidney which cannot be distinguished by $x$-ray or ultrasound scan from renal carcinoma. $^{5}$ The foam cells of xanthogranulomatous pyelonephritis may be indistinguishable from the clear cells of renal carcinoma on routine histological examination, and this may result in misinterpretation, particularly of fine needle biopsy specimens. ${ }^{6}$

We decided to apply the argyrophil nucleolar organiser region (AgNOR) enumeration technique to examples of renal adenoma, clear cell carcinoma, and xanthogranulomatous pyelonephritis in an attempt to facilitate diagnosis.

\section{Methods}

Seven cases of renal adenoma, nine cases of clear cell carcinoma, and five cases of xanthogranulomatous pyelonephritis were studied. The specimens of carcinoma and xanthogranulomatous pyelonephritis were obtained from nephrectomy specimens and the adenomas from necropsy material. The latter were all less than $3 \mathrm{~cm}$ in diameter, included solid, tubular, and papillary variants, and were without evidence of metastases.

Sections $3 \mu \mathrm{m}$ thick were cut from paraffin wax embedded blocks and were stained with the usual AgNOR solution. ${ }^{78}$ The AgNORs, which were seen as small black intranuclear dots, were counted in 100 consecutive tumour cells in adenoma and carcinoma, and macrophages in xanthogranulomatous pyelonephritis, from random fields. The mean AgNOR count per cell was calculated in each case. Sections of clear cell carcinoma and xanthogranulomatous pyelonephritis were also stained with a polyclonal antibody to epithelial membrane antigen (EMA) (The Binding Site, University of Birmingham Research Institute) using the avidin-biotin complex (ABC) technique, to substantiate these diagnoses. ${ }^{9}$

Statistical analysis was performed using the Mann Whitney U test.

\section{Results}

The mean AgNOR count per cell for renal adenoma was 2.02 (range 1.24-2.81); $95 \%$ confidence interval $1.40-2.63$; SD 0.66 ), for clear cell carcinoma was 3.06 (range 2.47-4.36; $95 \%$ confidence interval $2 \cdot 60-3 \cdot 51$; SD 0.59 ), and for xanthogranulomatous pyelonephritis was 1.65 (range $1.28-2.00 ; 95 \%$ confidence interval $1 \cdot 31-1 \cdot 99 ;$ SD $0 \cdot 27$ ) (figs $1-3$ ). The difference in mean AgNOR count between renal adnoma and clear cell carcinoma was not significant, but there was a significant difference in mean AgNOR count between carcinoma and xanthogranulomatous pyelonephritis $(\mathrm{p}<0.001)$.

Staining with anti-EMA was positive in each case of presumed adenoma and carcinoma and negative in each case of xanthogranulomatous pyelonephritis.

\section{Discussion}

AgNORs are segments of DNA in the cell nucleus which contain ribosomal RNA genes. The associated proteins (NORAPs) including RNA polymerase $1, B_{23}$ protein, and $C_{23}$ protein (nucleolin) are argyrophilic and stain with the AgNOR solution. AgNOR enumeration has been shown to be useful in differentiating certain conditions which may be difficult to distinguish using routine methods. These include benign melanocytic lesions and malignant melanoma, ${ }^{8}$ high and low grade lym- 


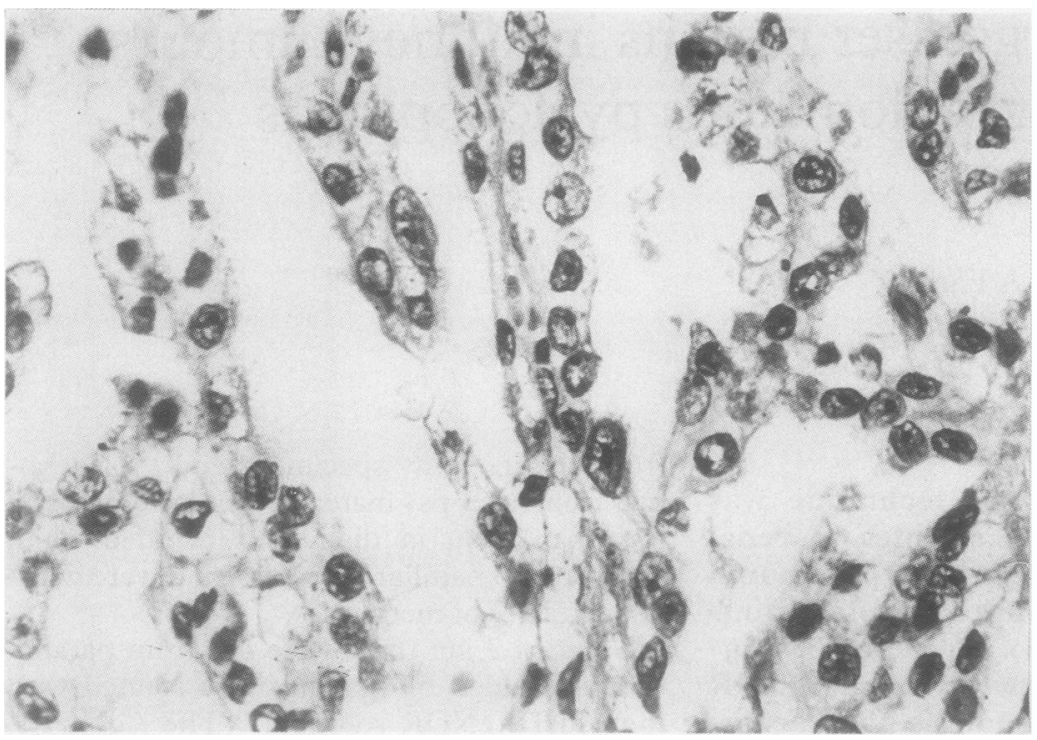

Figure 1 Renal adenoma. (AgNOR stain.)

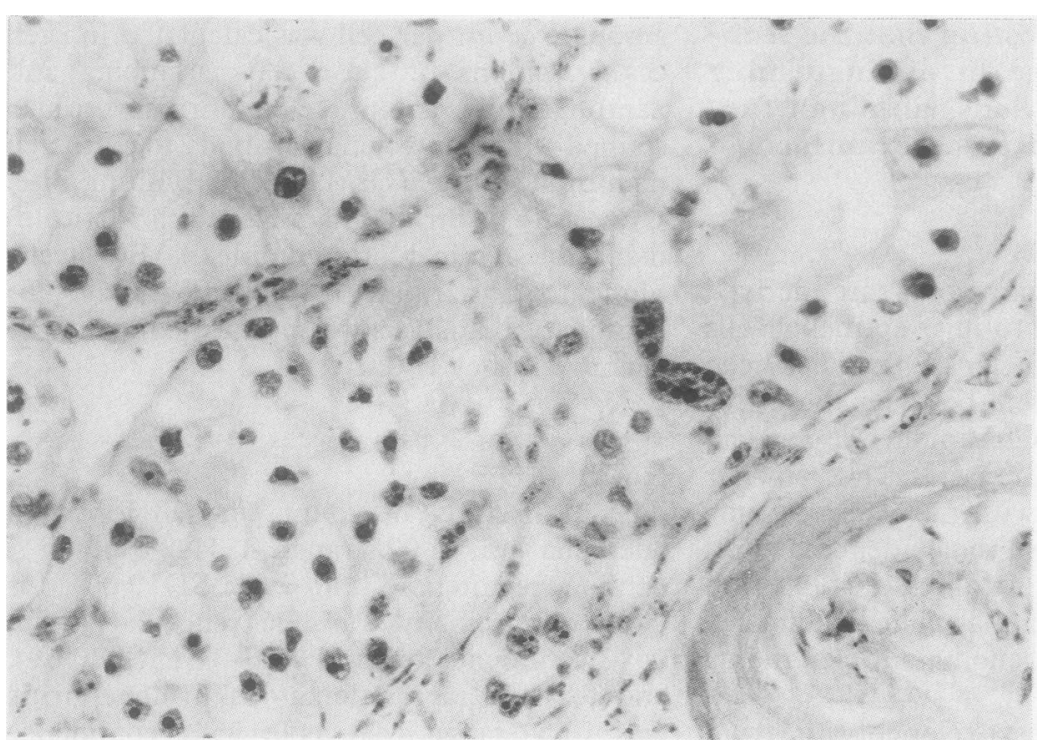

Figure 2 Clear cell carcinoma. (AgNOR stain.)

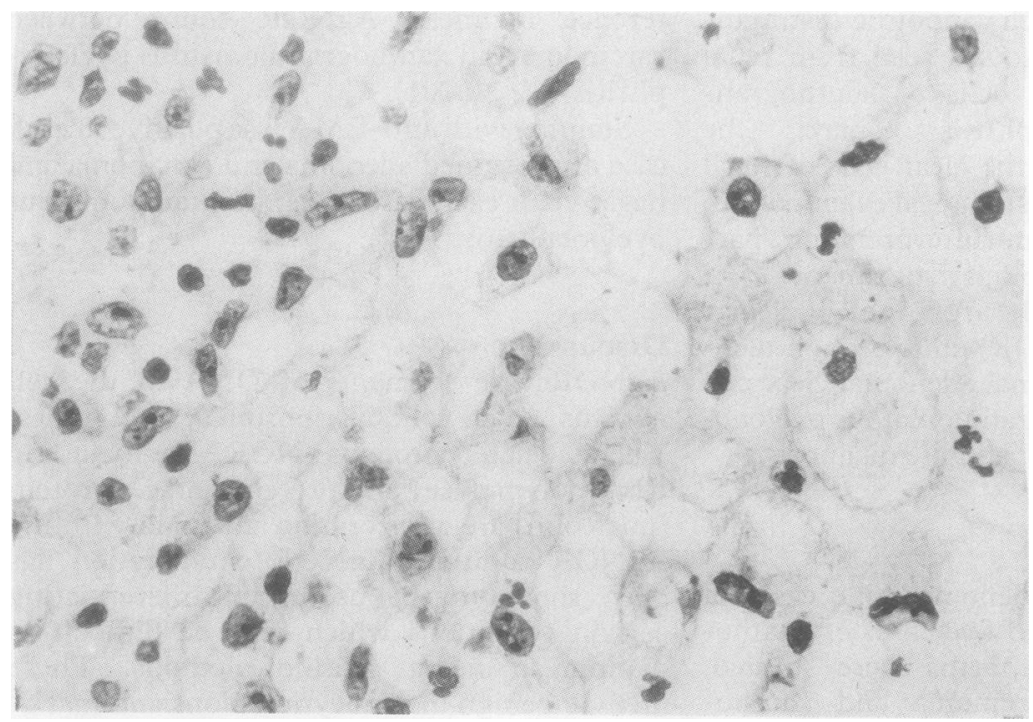

Figure 3 Xanthogranulomatous pyelonephritis. (AgNOR stain.) phoma, ${ }^{7}$ and infantile fibrosarcoma and benign fibrous proliferations of childhood. ${ }^{10}$ In each case higher AgNOR counts are associated with malignancy or more aggressive behaviour. This is thought to reflect the higher proliferation rates of malignant tumours when compared with benign tumours. Thus Hall et al showed a linear relation between AgNOR staining and Ki-67 immunoreactivity. ${ }^{11}$ Furthermore, cells labelled with this monoclonal antibody have high AgNOR counts;Ki-67 negative cells have one or two AgNORs. ${ }^{12}$

The mean AgNOR counts of clear cell carcinoma tended to be higher than those of renal adenoma, although the difference was not significant. This observation supports the idea that there is a continuous spectrum of these renal tumours, the larger ones tending to be associated with more malignant behaviour and probably a faster rate of growth. This may apply to renal adenoma and carcinoma, but the same argument is clearly not applicable to xanthogranulomatous pyelonephritis and renal adenoma, although their mean AgNOR counts are very similar.

The difference in AgNOR count between clear cell carcinoma and xanthogranulomatous pyelonephritis was significant, indicating that this technique may be of use in their differentiation, although further cases may need to be examined to confirm this. The technique may be of value, particularly in the interpretation of biopsy material in which the histological appearances of the two conditions may be identical. Positive staining with anti-EMA would further support a diagnosis of carcinoma and negative staining would favour a diagnosis of xanthogranulomatous pyelonephritis.

We thank Mrs V Garland for secretarial assistance.

1 Fisher ER, Horvat B. Comparative ultrastructural study of so-called renal adenoma and carcinoma. J Urol 1972, 180:382-6.

2 Wallace AC, Nairn RC. Renal tubular antigens in kidney tumours. Cancer 1972;29:977-81.

3 Fleming S, Lindop GBM, Gibson AAM. The distribution of epithelial membrane antigen in the kidney and its tumours. Histopathology 1985;9:729-39.

4 Benningham JL, Beckwith JB. Tumours of the kidney, renal pelvis and ureter. In: Atlas of tumour pathology. Series 2, Fascicle 12. Washington, DC: Armed Forces Institute of Pathology, 1975:94-9.

5 Antonakopoulos GN, Chapple CR, Newman J, et al. Xanthogranulomatous pyelonephritis. A reappraisal and immunohistochemical study. Arch Pathol Lab Med 1988;112:275-81.

6 Grainger RG, Longstaff AJ, Parsons MA. Xanthogranulomatous pyelonephritis. A reappraisal. Lancet 1982; 1398-401

7 Crocker J, Nar P, Nucleolar organiser regions in lymphomas. J Pathol 1987;151:111-18.

8 Crocker J, Skilbeck N. Nucleolar organiser region associated protein in melanocytic lesions of skin. A quantitative study. J Clin Pathol 1987;40:885-9.

9 Gouldesbrough DR, Bell JE, Gordon A. Use of immunohistochemical methods in the differential diagnosis between primary cerebellar haemangioblastoma and metastatic renal carcinoma. J Clin Pathol 1988;41:861-5.

10 Egan M, Raafat F, Crocker J, Smith K. Nucleolar organiser regions in fibrous proliferations of childhood and infantile fibrosarcoma. J Clin Pathol 1987;40:31-3.

11 Hall PA, Crocker J, Watts A, Stansfeld AG. A comparison of nucleolar organiser region staining and $\mathrm{Ki}-67$ immunonucleolar organiser region staining and Ki-67 immunostaining in non-

12 Murray PG, Boldy DAR, Crocker J, Ayres JG. Sequential demonstration of antigens and AgNORs in frozen and paraffin sections. J Pathol 1989;159:169-72. 